\title{
EVIL EYE BELIEF IN TURKISH CULTURE: MYTH OF EVIL EYE BEAD
}

\author{
Bilgen TUNCER MANZAKOĞLU \\ bilgentm@gmail.com \\ Saliha TÜRKMENOĞLU BERKAN \\ Doğuş University, Industrial Product Design Department \\ turkmenoglu saliha@yahoo.com
}

\begin{abstract}
Evil eye belief is found in many parts of the world and it plays a major social role in a large number of cultural contexts. The history of evil eye bead usage dated back to ancient times, but upon time it's meaning have been re-constructed by culture. This paper focused on an amulet based commodity "evil eye bead" used against evil eye and for ornament in Turkey. In order to analyze the myth of evil eye bead, two-sectioned survey was conducted. First section determined evil eye belief rate, participant profile and objects against evil eye. In the second section, the semantic dimensions of evil eye bead was analyzed in the myth level encompassing its perception and function as a cultural opponent act. This paper interrogated the role of culture, geography, and history on the evil eye bead myth.
\end{abstract}

Keywords: Evil Eye Bead, Culture, Myth, Semiology.

\section{TÜRK KÜLTÜRÜNDE NAZAR İNANCI: NAZAR BONCUĞU MITİ}

ÖZ

Nazar inancı dünyanın bir çok bölgesinde bulunmakta ve kültürel bağlamda önemli bir sosyal rol üstlenmektedir.Nazar boncuğunun kullanımı antik zamanlara dayanmakla birlikte, taşıdığı anlam zaman içerisinde kültür ile birlikte yeniden inşa edilmiştir. Türkiye'de hem süs eşyası hem de kem göze karşı kullanılan nazar boncuğu bu makalenin ana konusudur. Nazar boncuğu mitini analiz etmek için iki aşamalı anket çalışması yürütülmüştür. İlk aşamada nazara inanılıp inanılmadığı, katılımcı profili ve nazara karşı kullanılan nesneler belirlenmiştir. İkinci aşamada ise, nazar boncuğu, nazara karşı1 etken olarak semantic boyutları ile birlikte irdelenmiş̧ir.

Anahtar kelimeler: Nazar boncuğu, Kültür, Mit, Semiyotik

\section{EVIL EYE BELIEF}

When you feel completely happy, or love someone above all else, or laugh too much, or everything goes quite well in the same period, do you ever possessed of fear to lose it?

The evil eye phenomenon is the simple belief, based on the emotion of jealously, envy, desire, or admire to someone or something. Someone can cause harm by looking at another's property or person. This kind of belief is found in many parts of the world, and it plays a major social role in a large number of cultural contexts around the world (Maloney, 1976). The evil eye is commonly associated with envy, and conveyed by a look, touch or verbal expression of envy or by excessive admire and praise without a blessing (Elworthy 1895, 1-43).

In Turkish culture, there is also similar approach on the basis of evil eye beliefs, named as 'nazar'. The origin of the word is Arabic, means 'to look, to look at' (Er M., 2005:13; Hançerlioğlu, 1984). The term 'nazar' is used by means of 'eye touch' to be cause damage to human, livestock or object (Er M., 2005:13; Pakalın, 1972; Marcais 1960, 784-6). In ancient Turkish dictionary 'Divânu Lügati'tTürk', Kaşgarlı Mahmud defines evil eye as a fatal power that comes into being from bad effects and to ward it off "egit" - a kind of medicine, used for protection from evil eye - and "moncuk-boncuk"- 
precious stone hung on horse's neck- should be used. Yolcu implies that evil eye belief spread among people in three ways. First of all; ancient cultural beliefs transferred through generations. Second; after the birth of monotheist religions, they were combined with old cultural beliefs. Third; different migrations came and brought their culture from abroad and settled down in Anatolia (Yolcu, 2008). Former Turkish tribes also believed in evil eye and took precaution against it, such as Kazakhs attached amulets on their clothes, Gagauz Turks ${ }^{1}$ used amulets with cross (Güngör and Argunşah, 1991). It is possible to diversify samples of precautions taken in different periods and cultures, but many of these beliefs are grounded before the adoption of Islam. As well as the cultural reflections of geographic settlement, Islamic Doctrine based upon the statement of Propet Muhammad "The influence of an evil eye is a fact..." [Sahih Muslim, Book 26, Number 5427] intensified the belief; on the other hand evil eye is not clearly mentioned in Koran. The religion of Islam not only prohibited amulets and talismans for protection, but also banned doing sorcery by reason of damaging the monotheist structure of religion (Davut, nd.). Extended to primitive ages, the origin of the old beliefs maintaining its entity while transforming in time, and keep going to influence on individual's daily life and behaviors (Çıblak, 2004).

The belief of 'nazar' is not only prevalent in Turkey, but also very common in a large number of countries in which is named 'mauvais oeil' in France, 'elayn' or 'isabet-i ayn' or 'ayn al-asūd ( عين (الحسود ' in Arabia, 'evil eye' in America and England, 'böser blick' in Germany, 'matisma' in Greece, 'bed nezer' in Iran, 'sihi' in India and 'mal de ojo' in Latin America.

As a concept, a superstition, a religious belief, or as a belief complex, the evil eye is historically and geographically widespread, but has a long history within the region of the Mediterranean (DiStasi, 1981; Dundes, 1981; Francis, 1994; Migliore, 1997; Siebers, 1983). Recently it is known that evil eye belief, originated and spread from the Mediterranean basin. Elworthy (1958) and Story (2003) stated that it started in Classical Greece and later passed to ancient Rome (Figure 1). In classical Greek and Roman Mythology myth, one turn into stone that gazed into the eyes of snake haired Gorgon Medusa (DiStasi, 1981; Siebers, 1983). Briefly, the evil eye belief that originated primarily Mesopotamia and Middle East vary among different cultures and geographies (Thomsen, 1987).

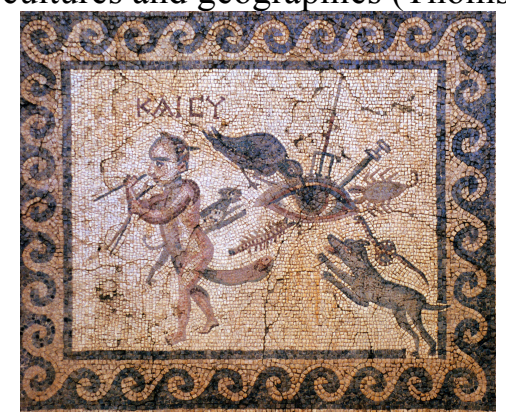

Figure 1. Roman-era mosaic from Antioch depicting a plethora of devices against the evil eye (Clarke, 2009)

Located near the Mediterranean and on a part of a territory of ancient Mesopotamia and Roma, the land of Anatolia in Turkey has a great cultural heritage including evil eye belief. As a part of a belief system, evil eye concept's roots vary upon culture and commodities of this concept gain different meanings. Analyzing topic within cultural context can give a deeper insight on meaning construction of belief.

\section{EVIL EYE AS A CULTURAL PRACTICE}

Brislin defines culture as a group of people who is connected with common beliefs, experiences, value and has a shared history (Brislin, 1981) that compose a prototype on individual's responses. According to Goodenough, culture includes standards on how and what might be the individual's attitude in what is going on and what can be done about it (Goodenough, 1961). Evil eye belief has a

\footnotetext{
${ }^{1}$ It is believed that wearing a stone as a necklace, or a plant, or wolf tooth, bear or eagle's claw can protect individual against evil eye. Ram's horn, ram and ship figure was placed on the amulets and charms obtained from old Hun graves (Araz, 1995).
} 
long history in Turkish Culture in which encoded rituals had been constituted by the time upon its meaning; how can individual be protected from it or how can individual be purified from its negative energy. These rituals evolved from past to present and became symbols of everyday life. Levi-Strauss accepts culture as a shared symbolic system created by the mind (Kartar1, 1999). Furthermore, this symbolic system, Öztürk defines as "created images", supports transfer of the national heritage (Öztürk, 1997; Ersoy, 2002). In this context, evil eye bead is a materialized form of cultural belief.

Cultural beliefs (they can be described as practices of culture) are composed of two forces (Acipayaml1, 1962).

1. Social values

2. Psychological Reaction

Social values create the frame of cultural practices and psychological reactions form the culturalopponent act. These two factors compose the Socio-Psychological Method. Evil eye belief can be regarded as a cultural practice and actions against evil eye can be regarded as cultural-opponent act. Evil eye cannot be solely regarded as a cultural case. A cultural practice and cultural-opponent act together composes a cultural case.

Different kind of cultural opponent acts against evil eye are prevalent all around the world. However, some amulets and rituals are unique to the region. In Turkey, Çıblak (2004:4-17) classified these opponent acts into two groups; protection methods against evil eye and rituals ${ }^{2}$ to remove the influence of it. Opponent acts or protection methods of Turkish culture can be divided into two groups: First is based on Islamic amulet 'muska" made by religion men (hodja) who never accept financial gaining for this kind of activity or pray $^{4}$ and say 'masha allah'; and second is based on cultural objects belong to different local areas and subcultures of Turkey such as evil eye bead, hand shape, horseshoe, turtle shell, animal head, ram horn, bell, perforated stone, mercury and eggshell (Çıblak, 2004). Çobanoğlu bring out in his thesis 'Superstitions Among People' that evil eye belief rate in Turkey is higher among people who pray regularly than that of not pray. But they do not prefer amulets to avoid from it; rather consider to pray $^{5}$ (Çobanoğlu, 2006).

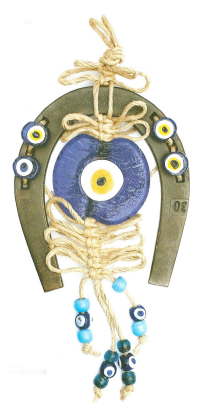

Figure 2. Horse shoe evil eye bead. (Çalış, E. and E. Çevik, 2010).

\begin{abstract}
${ }^{2}$ Lead Melting (Kurşun Dökme): Lead is put into a bucket or a small pan and melted in heat. On the other hand, patient sits on his/her knees and wears cheesecloth. Melted lead is poured to a water-filled container above patients' head, within a number of different words or prays.; Ember Extinguishing (Köz Söndürme): In Trabzon, if somebody is suspecting from evil eye, embers, gotten from fire, are discarded to a cup of water by saying the names of guests, who are suspected as the source of evil eye; Fumigation (Tütsleme): In Turks, incense has been used in treatment, magic and protection from evil eye. Usually olive is used in incense and it should have a plenty of smoke and while burning seeds of olive should have sound to be effective. Evil eye will disappear with this sound (Akalin, 1993: 257); and other rituals; rotating salt above the head or washing livestock with water affected by evil eye
\end{abstract}

${ }^{3}$ Evil eye amulet is made by hodja (prayer). One or more pray of Koran is written in a piece of paper, then folded up in a triangle form and covered with linoleum seven times, and put into a fabric cover to wear like a necklace.

${ }^{4}$ It is commonly known among Muslims that the protection can be achieved only by saying particular prays against evil eye such as 'surah al-falaq' and 'surah an-nas' and the use of talismans are prohibited.

${ }^{5}$ See footnote 3 
Prof. Dr. Ali Çarkoğlu and Prof. Dr. Ersin Kalaycığlu's (2009) study 'Devotion in Turkey: An International Comparison' analyzed that evil eye belief rate is \%35 and other beliefs like, magic, fortune telling etc. are only $\% 10$ rate. Survey results indicated that evil eye belief rate in Turk population approximately equal with worlds', but belief in other cultural practices (magic, fortune telling) is under the world rate. With the exception of evil eye, religion is dominant on other cultural beliefs and an important question arises 'how can a devout population accept the opponent act objects of evil eye belief rejected by religion?'

\section{METHODOLOGY}

Evil eye signals and receiver compose cultural practice. Receiver of this practice is the object or animal or individual, which is under attack of evil eye signals. If there is no cultural opponent act to send signals away from receiver,evil eye signals can cause damage on receiver (Figure 3).

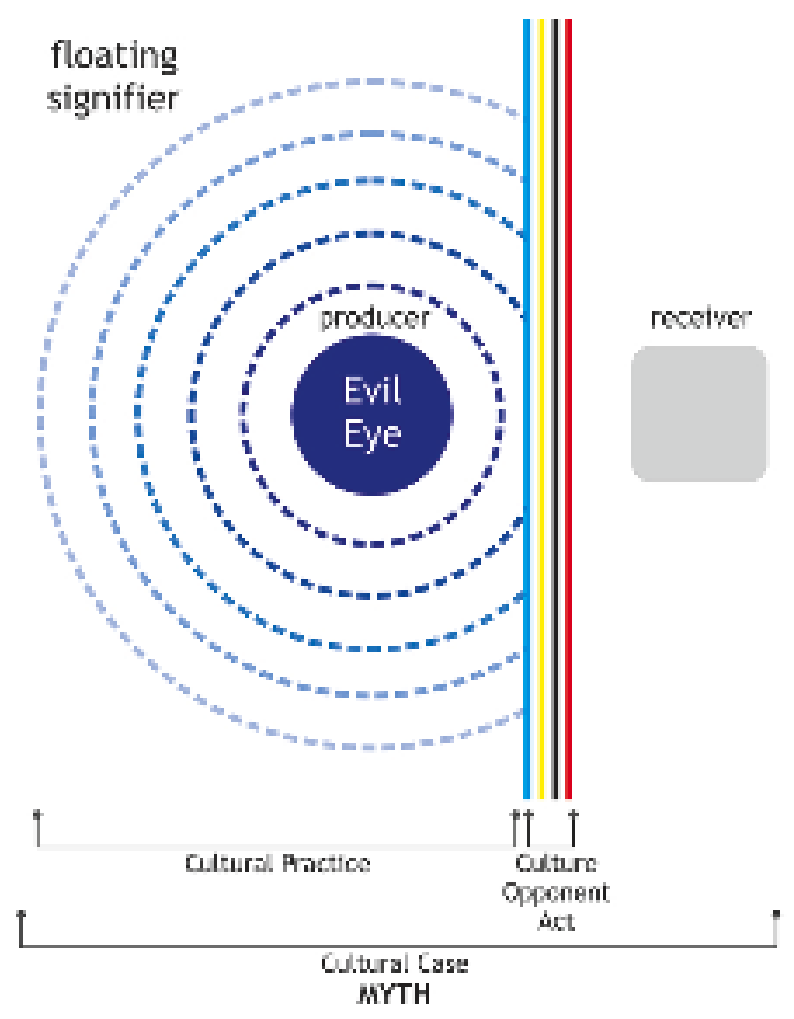

Figure 3. Cultural Case - Myth

Receiver is at the core of evil eye that exposed to signals of evil eye. As it doesn't sign same meaning for every person, it can be defined as floating signifier that signified changes upon culture or subculture. As a receiver, outstandingly beautiful or healthy people are thought to be especially vulnerable to it (Shiloh 1961, 277-88). The study was conducted in two sections. The fist survey has been conducted to decode "producer", "receiver" and "opponent-act". Participant profile was defined,, cultural opponent act and its artifacts were determined as receiver of glance or energy. The common acceptance of evil eye bead as a sign (or symbol) was proved in spite of the objection of Islam against amulets.

In the second section, as a non-Islamic amulet, the meaning of evil eye bead was analyzed in the myth level in terms of semiology, its perception and function was questioned as a cultural opponent act. To gain an understanding of meaning, randomly selected 20 participants (10 man, 10 women), were interviewed with six open-ended questions. Thanks to the information gathered from participants, myth of evil eye bead was analyzed as a sign of evil eye in terms of denotation and connotation. 


\section{FIRST SECTION RESULTS}

Survey's first section was conducted with 122 people; \%63 female and \% 37 male. All options in questionnaire selected from relevant literature. Average age of participant group was 35,5 and their educational level; \%62 have associate or university degree, $\% 24$ have master or doctorate degree, $\% 10$ have high school or secondary degree and \%4 have primary school degree. Participants' \% 84 believed in evil eye, and $\% 72$ of them needs opponent-act for protection.

In spite of the conventional wisdom, womenfolk believe in evil eye much more than men, percentages indicated that evil eye belief ratio doesn't change upon gender. Evil eye belief is generally associated with uneducated and country people (Zammit G. and Maempel, 1968), however \% 82,70 of educated participants (Associate Degree, University Degree, Master Degree, Doctorate Degree) believed in evil eye and $\% 38,30$ of them consider that evil eye is something to be avoided.

Participants were inquired to identify receiver and gave receiver role mostly to people (happy couples, lucky people, people who are successful in their jobs, successful students). Objects had minimum role as receiver (Figure 4). So it could be said that participants mostly thought receiver as organic in material. Most participants think that receivers do not need to have special qualifications, while other half think receiver should be outstanding and beautiful.

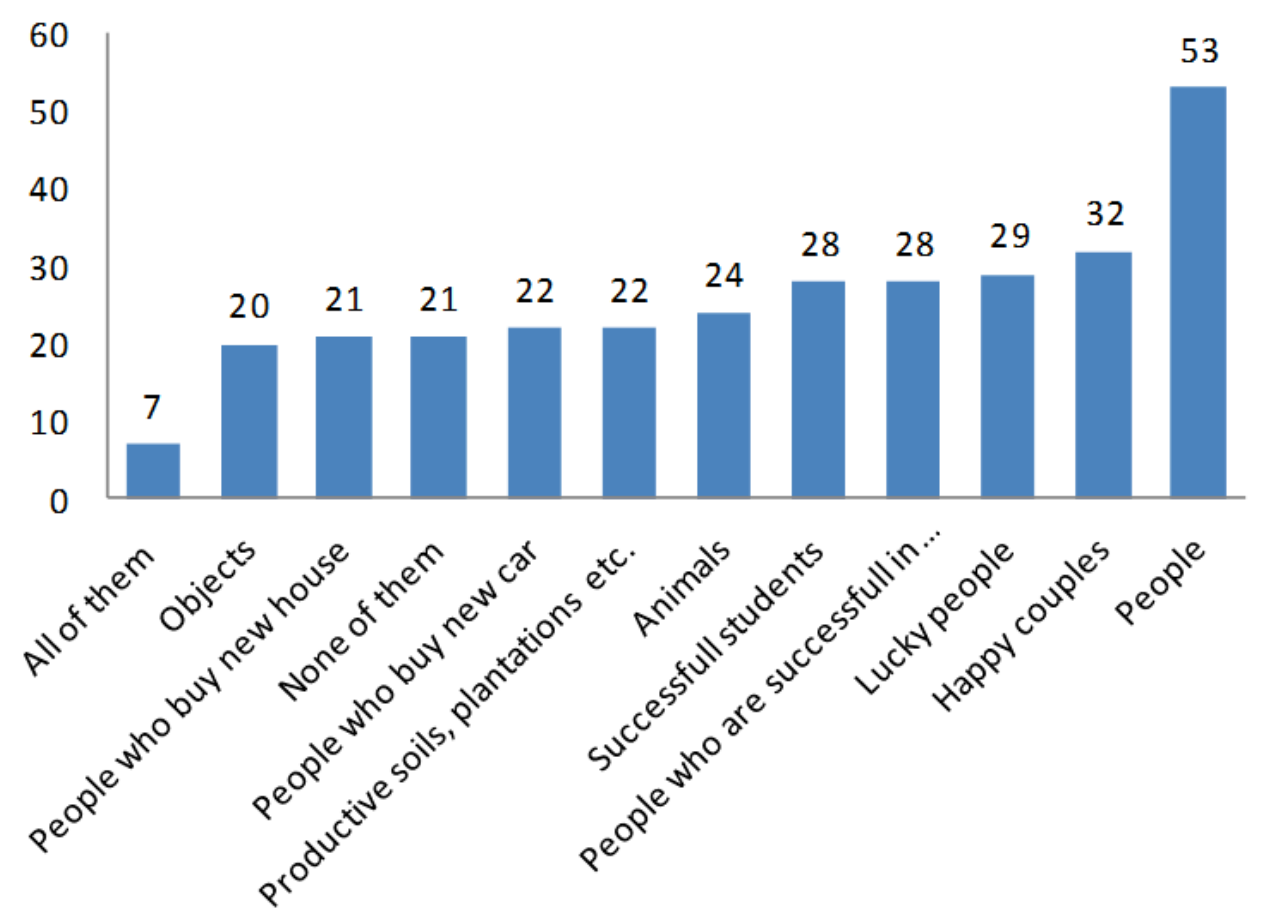

Figure 4. Receiver of evil eye

The source of evil eye is generally determined as bad thought (\% 41) and admire (\%29), only few (\%22) participants believe that it occurs without anyone's intention. In literature, evil eye source has been described mostly by glance, but different types of sources like speech, psyche or puff has been mentioned, as well. Participants were asked, "Which of the followings cause evil eye?" Close ratios derived from answers; \%35 Glance; \%29 Psyche; \%23 Speech or Sound; \%13 Puff. Eye symbolization in evil eye artifacts directly linked to the glance. As to argue from analogy, eye became the intermediary to defect evil eye. 


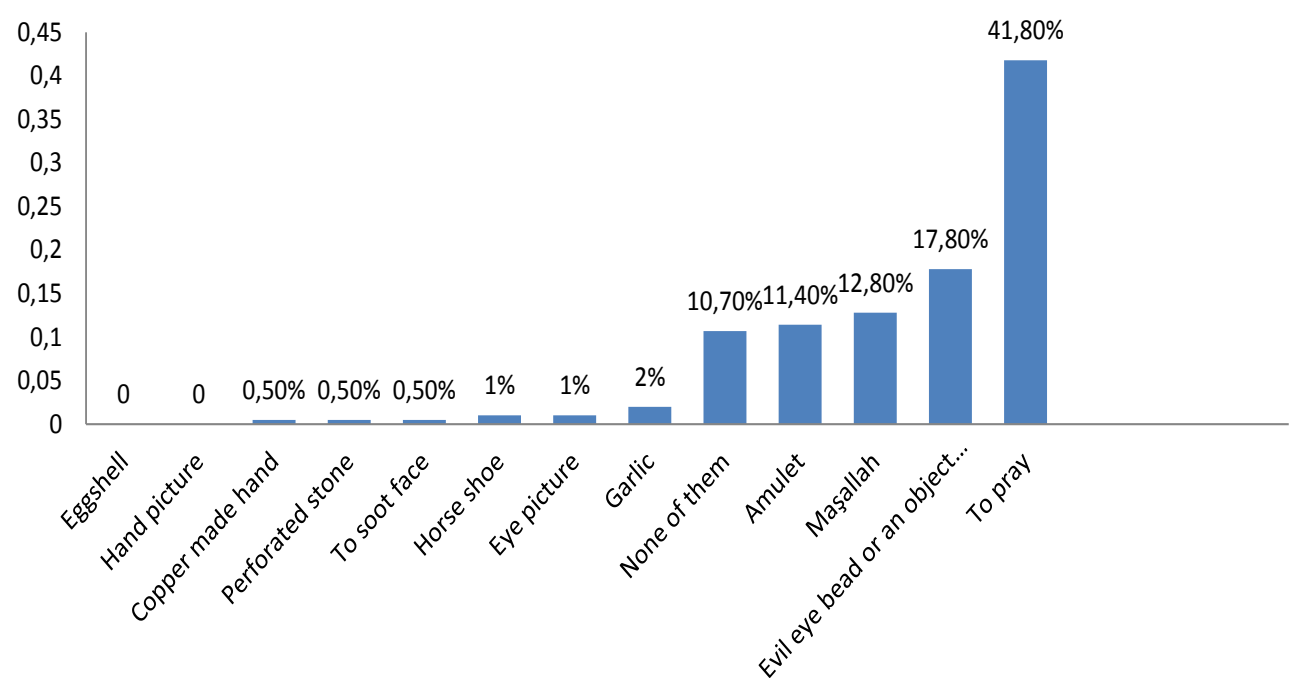

Figure 5. The opponent act (protection) of evil eye

Evil eye belief can be summarized as glance sourced; being from jealous or bad ideas and mostly affects people or affecting an object. The most outstanding opponent acts are determined as pray, evil eye bead, maşallah and amulet. Although high acceptation of religious methods like Maşallah and islamic amulets, the commodity value of evil eye bead is more common (see Figure 5). Evil eye bead could be described as a souvenir product mostly brought by somebody else as a gift (\%34). It is one of the favorable way to show the best wishes to someone who has a new house, car, or a new way of life. These results indicate that educational level, age and gender have no significant impact on the individuals' evil eye belief. In the literature evil eye belief is generally related with ignorance, philistinism, agriculture and country life. The belief originated in the Near East with the evolution of complex peasant-urban cultures and spread in all directions (Maloney, 1976). Today having a university, doctoral, or primary school degree do not impact people, but culture/tradition have the greatest impact on evil eye belief of individuals. Another significant result was the receiver of evil eye could be an object as well as an individual. Beside religious protection methods, cultural objects have been used to ward off evil eye from individual for many years. Depart from all of them, evil eye bead is the most outstanding cultural opponent act representing protection, history, tradition, ornament and social practices in its meaning as a commodity product.

\section{MYTH OF EVIL EYE BEAD}

Having a significant role in social life, signs are studied in semiology as a science (Chandler, 2005; Barthes, 1993; Eco, 1976: 7). Semiotics became a major approach at cultural studies in 1960s with the contribution of Roland Barthes. He took in systems of signs, whatever their substance and limits: objects, images, gestures, words, musical sounds and complex associations of all of these (Barthes, 1967: 9). In addition, Chandler (2005) stated that signs can take the form of words, objects, images, flavors and art when we assign meaning. Evil eye bead is analyzed as a sign in terms of its denotative (signifier) and connotative (signified) meanings. The denotation is the form, the connotation is the meaning (which is mental) and the relation between form and meaning is the sign (Figure 6) (Barthes, 1993). Denotation and connotation combined to produce ideology, myth is the naturalization of ideology. Myth makes dominant cultural and historical values, attitudes and beliefs seem entirely normal and natural (Barthes, 1977, 45-46). 


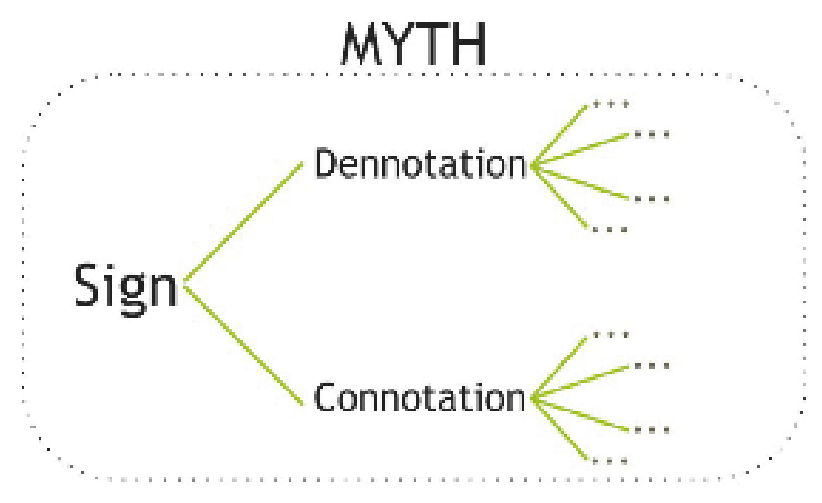

Figure 6. Structure of myth

Myth has double function: points out and notifies, makes us understand something and imposes on us. It is this constant game of hide - and - seek between connotation and denotation, which defines myth (Chandler, 2005). In Turkey, the most outstanding object as a sign of evil eye is evil eye bead that carries meaning, history, traditional knowledge and practice in myth context. The analysis of evil eye bead depends on denotative and connotative signifiers of evil eye myth, thus a qualitative research has performed with university degree 10 women and 10 men, age average 34 . Four open-ended questions were structured to investigate the denotation and connotation of evil eye beads. Chandler stated that methodologies in semiotic analyzes are qualitative (Chandler, 2005). Osgood et al. (1957), in his book 'The Measurement of Meaning' introduced a qualitative technique for the systematic mapping of connotations. In technique, people are asked to give impressionistic responses to a particular sign by using a pencil and paper. In this context, paper and basic colored pencils were given to participants to draw an imagined evil eye bead (Figure 7). Purpose of the question is to analyze form and color codes of object.

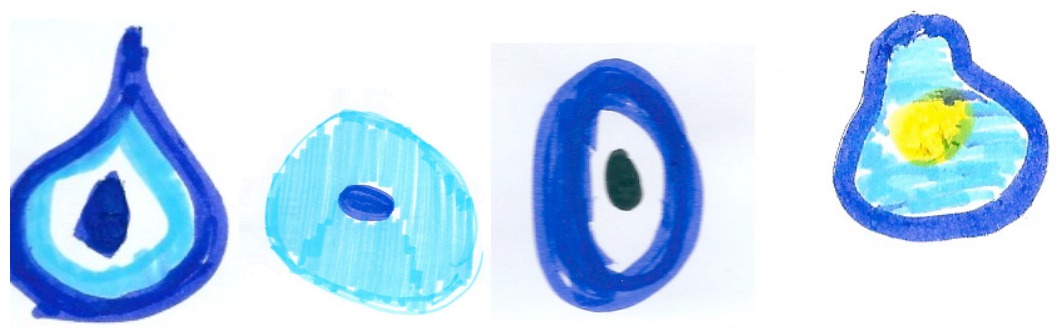

Figure 7. A few drawings of participants.

10 beads were drawn in circle, 8 beads in elliptical, 2 beads in drop, and one bead in flower form. 18 rounded forms symbolizing the protection from evil eye can be regarded as the repeated form of eye. Therefore, according to analogy principle, source of the evil could be defected or destroyed only with its similar (Çıblak, 2004). Moreover, Jay pointed that an amulet's power is based on its color, shape or material, which have acquired meaning from different beliefs (Jay, 1996).

Turks generally have been a brown-colored society and blue-green eyed individuals are rare, so that public believed color-eyed individuals cause evil eye (Çıblak, 2004 and Acıpayaml, 1962 and Abdülkadir, 1963). In ancient times, Central Asian people believed to the god of sky, Tengri Ülgen, that sits in the heavens and protects people from evil. Therefore, people regarded the color of blue sky as sacred color and used for protection (Erginer, 2006).

Arrangement of colors from outside to inside is important to attract the evil eye. In common, blue rounded color placed at the outer line, followed by white or yellow, and black or dark blue placed at the center of form. The defensive strategy consists of distracting the eye by making it look at something other than receivers' eye. Representatives of eyes, whether dots, circles, circle/dots or more complex motifs are extensively used for this purpose (Francis, 1994). 
As a result of technological developments, today, different colors of evil eye beads are prevalent, but survey indicates those participants' perceptions about evil eye still overlaps with blue color. Color and form emerged as one of the denotative level.

Three evil eye bead differentiate in material, including glass, plastic and two-dimensional stickers given to participants and 13 of them were emphasized the importance of glass material with color and form to ward off evil eye. It is believed that glass bead should be broken down under the effect of evil eye. Seven participants did not make any discrimination between material and form; they believe just in evil eye myth, not object as an opponent act. These individuals considered evil eye beads as aesthetic objects for ornament and made their choices according to ease of usage, such as plastic sticker or paper sticker.

Although all of the 20 participants are believed in evil eye, 12 of them gave importance to evil eye bead as an object. For other 8 participants, all evil eye figures are similar because all of them symbolize the evil eye concept, thus it is the main sign of evil eye myth in Turkish culture. Both of them have respect to traditional values in which evil eye beads and its usage diversified.

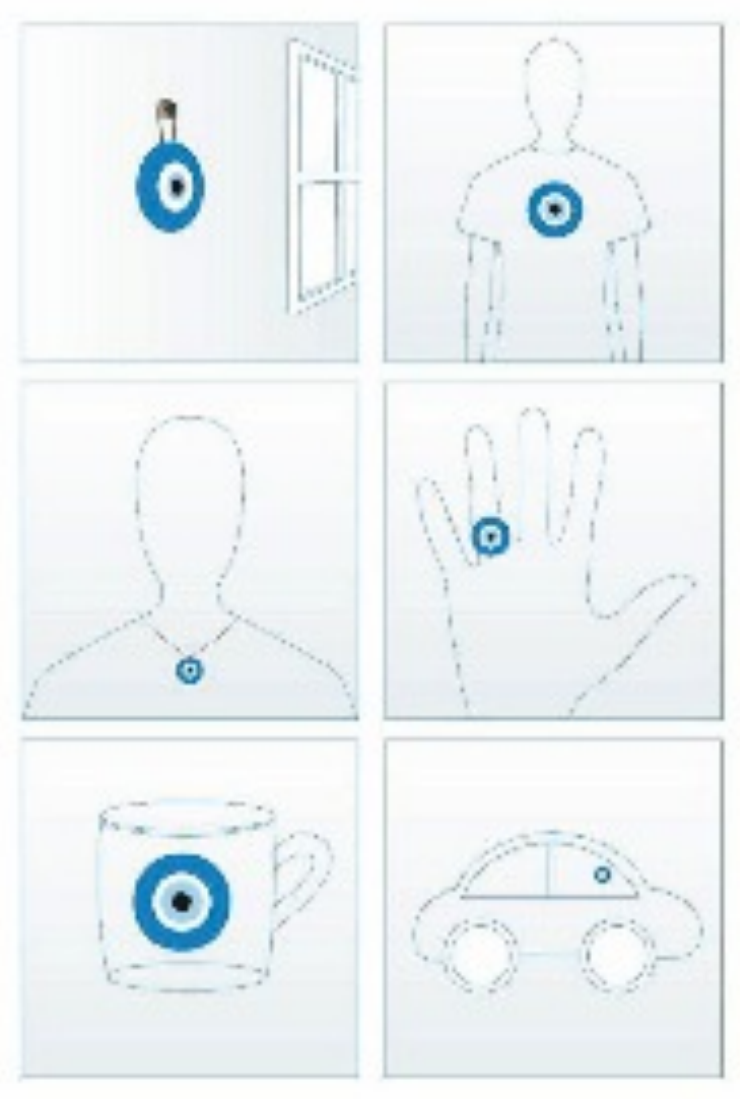

Figure 8. Survey sheet. 


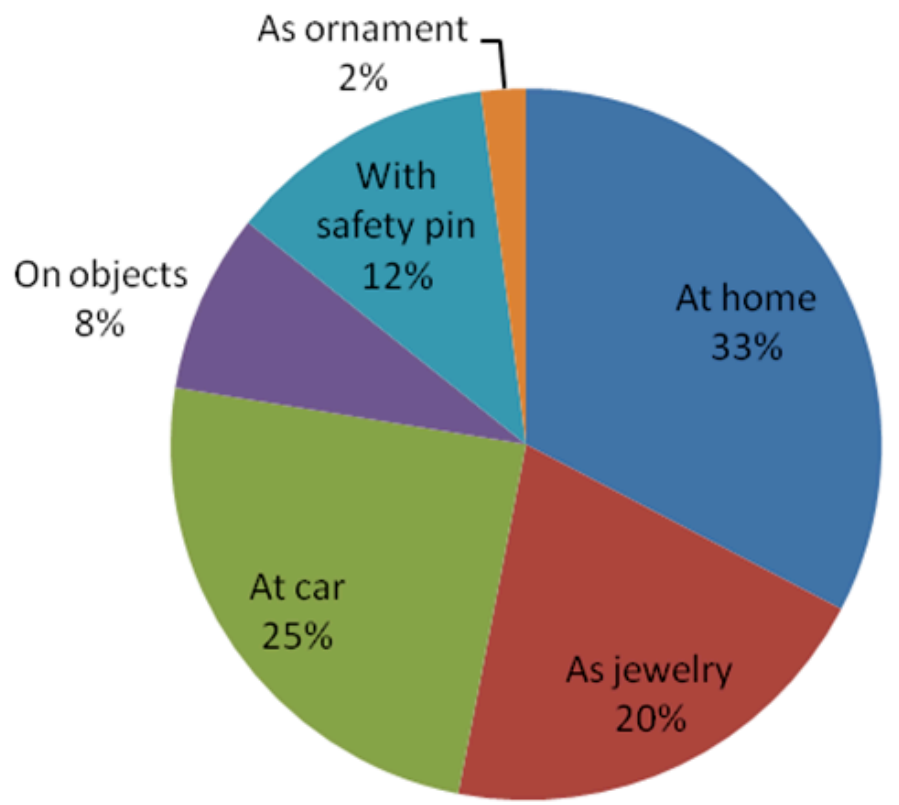

Figure 9. Evil eye bead usage

A set of pictures had shown to identify the meaning and usage (see Figure 9) Close relations between relatives, friends, neighbors...etc. are frequently meeting at home, therefore evil eye bead is usually used at home to protect household.

Cars take the second place in consideration of attracting evil eye. Thus, evil eye beads are commonly in use on cars to prevent accidents. Also, it is known that ancient Turks were frequently hang beads on their horses. Finally, evil eye beads are mostly placed on jewelers for personal use as ornament. In usage of evil eye bead, participants were divided into two groups; first group believes that evil eye bead should be seen by others to distract the individual's attention or look. After absorbing bad look, evil eye bead is believed to be broken. This group usually declared that the place of evil eye bead is home, car, and their body. In addition to the placement, the arrangement of colors and the material of beads are considerably important to be protective.

Second group did not give importance to show it to others, and mostly marked safety pin (bead attached to it). Ease of usage on a fabric makes safety pin bead very favorable in Turkish culture (Figure 10). Particularly, small glass beads are used for babies and small children on their clothes, near their beds, and on pushchairs.

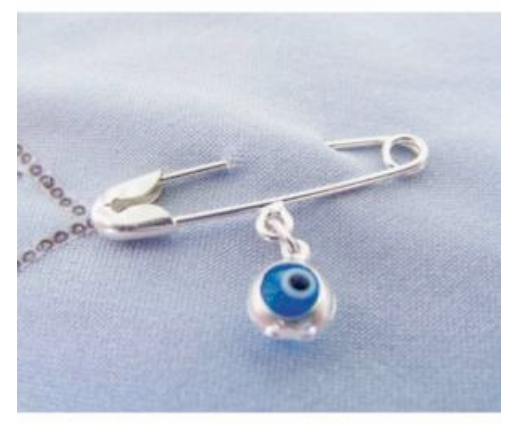

Figure 10. Evil eye bead with safety pin. Picture taken on 15.11.2011.

Evil eye beads were discriminated as real or fake according to their material and usage. Despite the manufacturers endeavor to expand the market with wide variety of beads in different color and material options, most people defined a classic evil eye bead as a sign of evil eye by means of their cultural codes. 


\section{CONCLUSION}

Evil eye bead is inherited from ancient times with overfilled meanings and significant forms, and today come out as a everyday artifact. We frequently come across with these signs on a taxi, on shop signboard, on paper tissue package, on sugar bowl at the buffet. Society grows up with these kind of signs and adopting the ideology of evil eye myth unconsciously. In this context, the high evil eye belief rate in well-educated people is related with the geographical and cultural factors. Since evil eye was defined as a floating signifier, its source was not given in place in this study.

Study was conducted in two sections; firstly, participant profile was determined, and the common acceptance of evil eye bead as a sign was proved despite the objection of Islam against amulets.

In the second section, the meaning of evil eye bead was analyzed in the myth level in terms of semiology, also its perception and function was questioned as a cultural opponent act (Figure 11). Thanks to the information gathered from participants, myth of evil eye bead was analyzed as a sign of evil eye in terms of denotation and connotation.

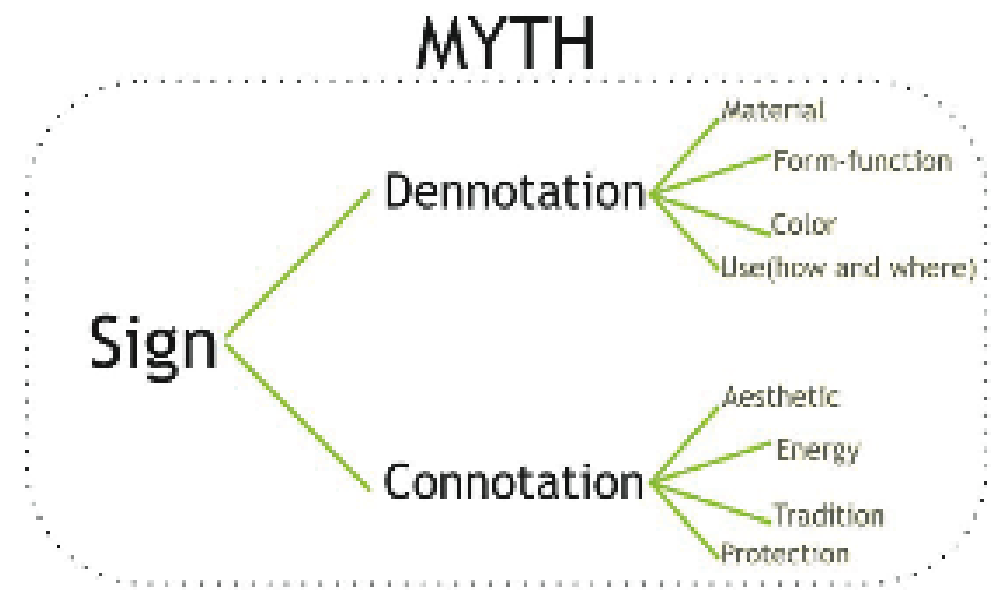

Figure 11. Analysis of evil eye bead in the myth context

The denotation of evil eye bead, consist of its material, form-function, color and use. Aesthetic, energy, tradition and protection features of sign were examined in the connotation level. These keywords can be combined each other and compose different signs to different people. For instance; material and color is important to a person believes in protection feature or; form-function and use is more important to a person believes in aesthetic feature. Form and meaning of artifact concrete entity of myth, which makes the ideology of evil eye entirely normal and natural. Hence, evil eye belief is commonly accepted by every segment of society whether educated or not.

As the result of naturalization of myth, evil eye bead has a pervasive usage as souvenir in Turkey. Buying evil eye bead as a gift is very favorable in Turkish culture to indicate the message of greetings when someone married, buy a new house, car, or enter a new business. This indicates that social structure and practices affect the individuals' perceptions, attitudes and beliefs. The knowledge from history and geography has been maintaining its impact intensively and consistently on individuals through evil eye myth. Even people do not believe in protective feature, they have attached value and respect to evil eye bead on account of symbolizing culture and tradition.

\section{REFERENCES}

Acıpayamlı, O. (1962). Anadolu'da Nazarla İlgili Bazı Adet ve İnanmalar. (Some Traditions and Beliefs About Evil Eye in Anatolia). AÜ DTCFD. C. XX. S. 1-2. 17-38.

Akalın, H., (1993). Üzerlik, II. Uluslararası Karacaoğlan ve Çukurova Halk Kültürü Sempozyumu (Symposium of the International Folk Culture Karacaoğlan and Cukurova). 20-22 November 1991 Adana. (pp.247-260). Preceedings, Adana, Çukurova University Press.

Araz, R., (1995). Harput'ta Eski Türk Inançlarl ve Halk Hekimliği (Harput Old Turkish Beliefs and 
Folk Medicine). Atatürk Kültür Dil ve TarihYüksek Kurumu. Atatürk Kültür Merkezi Yayını No: 108. Ankara. Levent Ofset Mat.Yay. Ltd. Şti,

Barthes, R. (1967). Elements of Semiology (trans. Annette Lavers \& Colin Smith). London: Jonathan Cape.

Barthes, R. (1977). Image-Music-Text. London: Fontana.

Barthes, R. (1993). Myth Today. Mythologies. London: Vintage.

Brislin, R.W. (1981). Cross-Cultural Encounters: Face to Face Interaction. USA. Pergamon Press.

Campbell, J. K. (1964). Honour, Family, and Patronage: A Study of Institutions and Moral Values in a Greek Moun-tain Community. Oxford: Clarendon Press.

Chandler, D. (2005). Semiotics for Beginners: Denotation, Connotation and Myth. Retrieved November 10, 2011, from http://www.aber.ac.uk/media/Documents/S4B/sem06.html

Clarke. (2009). Roman-era mosaic from Antioch depicting a plethora of devices against the evil eye. Hatay Archeology Museum. Antakya Inv. Nr. 1024. Turkey.

Çalış, E. \& E. Çevik, (2010). Evil Eye Bead. Material Culture Series 34 (pp: 353-2) Republic of Turkish Culture and Tourism Ministry Press.

Çarkoğlu, A. \& Kalaycığlu, E. (2009). Türkiye'de Dindarlık: Uluslararası Bir Karşılaş̧tırma (Religiosity in Turkey: An International Comparison) (Tech. Rep. ID:SU_FASS_2010/0002). Sabanc1 University.

Çıblak, N. (2004). Halk Kültüründe Nazar, Nazarlık İnancı ve Bunlara Bağlı Uygulamalar. (Evil Eye, Evil Eye Belief and Practices Related to Evil Eye) Türklük Bilimi Araştırmaları (Turkish Science Research). (15):103-125.

Çobanoğlu, A. (2006). Halk Arasında Yaşayan Hurafeler Üzerine Bir Alan Araştırması: Bursa/Osmangazi Örneği (A Case Study on Folk Superstitions in Public: Bursa/Osmangazi Case). Unpublished master thesis, Department of Basic Islamic Sciences, Sakarya University.

DiStasi, L. (1981). Mal'occhio: The underside of vision. San Francisco: North Point Press.

du Boulay, J. (1974). Portrait of a Greek Mountain Village. Oxford: Clarendon Press.

Dundes, A. (1981). Wet and Dry, the Evil Eye: An Essay in Indo-European and Semitic Worldview. In The Evil Eye: A Folklore Casebook, ed. Alan Dundes. (pp:257-98). New York and London: Garland Publishing.

Eco, U. (1976). A Theory of Semiotics. Bloomington. IN: Indiana University Press/London: Macmillan.

Edwards, D. (1971). The Evil Eye and Middle East Culture. Folklore Annual (Austin, Texas) 3: 3340.

Elworthy, F. T. (1895). The Evil Eye: An Account of this Ancient and Widespread Superstition. London: John Murray.

Elworthy, F. T. (1958). The Evil Eye: An Account of this Ancient and Widespread Superstition. p. 5. Forgotten Books. ed.

Er, M. (2005). Elazığ'da Nazarla İlgili İşlemlerin Sosyolojik Etkisi (Sociological Effects of Evil Eye Rituals in Elazığ) (Unpublished master's thesis), Social Sciences Institute. Department of Philosophy Religion Sciences. Firat University.

Erginer, G. (2006). Elemterefiş / Anadolu'da Büyü ve İnanışlar. Yapı Kredi Yayınları.

Ersoy, R. (2002). Folklorda Üçüncü Boyut Meselesi ve Avustralya Koalaları Örneği (Third Dimansion in Folklore and Australian Koala Case), Türkiye'de Halk Bilimi Müzeciliği ve Sorunlar Sempozyumu (Symposium on Public Science Museums and Its Problems in Turkey), Ankara, 12 - 13 December.

Evans-Pritchard \& Edward E. (1937). Witchcraft, Oracles and Magic Among the Azande. London: Oxford University Press.

Foster, George M. (1972). The Anatomy of Envy: A Study in Symbolic Behaviour. Current Anthropology 13 (2): 165-202.

Francis, P., Jr. (1994). Beads of the world: A collector's guide with price reference. Atglen, PA: Schiffer Publishing, Ltd.

Goodenough, W.H. (1961). Comment on Cultural Evolution. Deadulus 90: 521-28.

Granqvist, H. (1947). Child Problems Among the Arabs. Helsingfors: Soderstrom.

Güngör H., \& Argunşah, M. (1990). Gagauz Türkleri.-Tarih, Dil, Folklor, Halk Edebiyatı. Ankara: 
Kültür BakanlığıYayınları.

Hançerlioğlu, O. (1984). İslam Inançları Sözlüğü (Islamic Beliefs Dictionary)(pp: 419-420). Remzi Kitabevi. İstanbul.

Jay, S. (1996). Amulet. In J. Turner, (Ed.) The dictionary o f art. London: Macmillan.

Kartarı, A. (1999). Kültürlerarası İletişim ve Bir Araştırma Projesi (Intercultural Communication and a Research Project), Retrieved January 1, 2012 from http://turkoloji.cu.edu.tr/HALKBILIM/33.php

Maloney, C. (Ed.). (1976). The evil eye. New York: Columbia University Press.

Marcais, P. (1960). Ayn and Evil Eye. In H. A. R (Eds). In Encyclopaedia of Islam. (pp: 784-6). Gibb Leiden: Brill.

Migliore, S. (1997). Mal'uocchiu: Ambiguity, evil eye, and the language of distress. Toronto: University of Toronto Press.

Osgood, C.E., Suci, G.J., \& Tannenbaum, P.H. (1957). The Measurement of Meaning. Urbana, USA: University of Illinois Press.

Öztürk, A. O. (1997). Imaj Yazllarl (Image Writings). Konya. Gökhan Ajans.

Pakalın, M. Z. (1972). Osmanlı Tarih Deyimleri ve Terimleri Sözlüğ̈̈ (Ottoman History Statements and Terms Glossary). (pg: 665). MEB Yay. C.II. İstanbul.

Shiloh, A. (1961). The System of Medicine in Middle East Culture. Middle East Journal (15): 277-88.

Siebers, T. (1983). The Mirror of Medusa. Berkeley: University of California Press.

Spooner, B. (1976). The Evil Eye in the Middle East. In The Evil Eye, ed. C. Maloney. 76-84. New York: Columbia University Press.

Stillman, Y. (1970). The Evil Eye in Morocco. In Folklore Research Center Studies 1, eds. Dov Noy and Issachar Ben Ami. pp: 81-94. Jerusalem: Magnes Press.

Story, W. (2003). Castle St. Angelo and the Evil Eye. Kessinger Publishing. ed. (pp. 149-52).

Thomsen, (1987). Zauberdiagnose und Schwarze Magie in Mesopotamien. Carsten Niebuhr Institute Publi-cations (Copenhagen, 1987) (pp. 50-57).

Torntore, J. (1999). The Italian Coral Horn as an Object of Intimate Cultural Expression and Meaning. (Unpublished master thesis). University of Minnesota, December.

Westermarck, E. (1926). Ritual and Belief in Morocco. 2 vols. London: Macmillan.

Westermarck, E. (1961). Nazar Değmesi Inancı. Ankara. Yeni Matbaa.

Yolcu, F. (2008). Adana İli Ceyhan İlçesi Halk Kültürü Araştırması. (Unpublished master thesis). Department of Turkish Language and Literature, Çukurova University, 87.

Zammit G. \& Maempel, (1968). The Evil Eye and Protective Cattle Horns in Malta. Folklore, 79: 116. Published by: Taylor \& Francis, Ltd. on behalf of Folklore Enterprises, Ltd. Retrieved November 212011 from

URL: http://www.jstor.org/stable/1259289 